Tropical Agricultural Pesearch \& Extension 22 (3 \& 4): 2019

\title{
A SEQUENTIAL BATCH COMPOSTER FOR THE MANAGEMENT OF KITCHEN AND GARDEN WASTE IN RESTAURANTS AND GUEST HOUSES
}

\author{
Wijetunga S* and Karunarathne RSP
}

\author{
Department of Agricultural Engineering, Faculty of Agriculture, University of Ruhuna, \\ Mapalana, Kamburupitiya, Sri Lanka
}

\begin{abstract}
The disposal of solid waste is the last operation of solid waste management. Composting can be considered as an attractive onsite waste disposal option for the management of organic solid wastes. The medium-scale waste generators $(25-50 \mathrm{~kg} / \mathrm{day})$ do not have proper, adaptive technology for the production of compost. Therefore an attempt was taken to design, construct and evaluate a medium-scale composting bin system for the management of organic waste in restaurants and guest houses. The composting structures designed were installed in Kataragama town. Kitchen and garden waste was used as raw material. The first composting system is composed of six bins while the second system had only four bins. The six bins system was operated using only six bins for the total composting period while the other was operated using four bins. The kitchen and garden waste mixture (3:1) was used for the composting. Waste in the first week was added to the first bin and then degrading waste in the first bin was transferred to the next bin in the second week. This procedure was followed until the completion the compost production. Temperature is recorded daily while $\mathrm{pH}, \mathrm{EC}$, nitrogen and organic carbon were measured once a week. The selected physical and chemical parameters of the compost were also determined. The quality parameters in both rotation systems are almost similar to the compost standards given by Sri Lanka standard institute. The four bin rotation system is quite complex than the six bin rotation system and therefore, a six bin rotation system can be recommended since it can be operated easily. Based on the results of the study, the designed composter can be successfully used for the production of compost from kitchen and garden waste.
\end{abstract}

Keywords: Compost, Compost bins, Kitchen waste, Restaurant waste

\section{INTRODUCTION}

The safe disposal of waste is one of the biggest problems in the world. The growth of population and demand for new necessities intensify the problem. Moreover, the gathering of people seeking more facilities intensifies the municipal solid waste (MSW) disposal problem in towns and cities. The municipal solid wastes refer to the materials that have no value to the concerned person and that cannot be discharged through the drainage lines and they are generated domestically, commercially, industrially and through health care and gardening activities (Vuai 2010). The safe disposal of MSW having different materials is a big challenge for local authorities (Gunaruwan and Gunasekara 2016). Even though methods have been developed and are being developed for the management of MSW, it is not possible to apply the same method for all locations where

\footnotetext{
*Corresponding author: swije@agri.ruh.ac.lk
}

wastes are generated. The suitable methods should be selected or developed based on the quality and quantity of wastes, economic status of the local authority, technical know-how of the management personals and climatic and geographical conditions of the area.

The total estimated MSW generation in Sri Lanka is 10,768 t/per day in the year 2013 (JICA 2016) and now it may be more than 15,000 t per day according to the population and economic growth rates. The waste generation rate in the local authorities of Municipal Council, Urban Council and Pradeshiya Sabhas (smallest administrative unit of the local authority) is not equal and it varies depending on several factors. However, it is estimated that the waste generation potential in Sri Lanka in 2015 was $1.297 \mathrm{~kg} /$ person/day and is being increased due to the economic growth of the country (JICA 2016). The most prevalent final waste disposal method practice in 
most of the local authorities in Sri Lanka is open dumping due to low cost, ease to practice and less technology involved. The open dumping of wastes creates detrimental effects on the environment and health hazards for flora and fauna. However, the dumping of collected wastes in the places which are richer in biodiversities such as river banks, roadsides, wetlands and marshes are frequently practiced by local authorities in Sri Lanka (Gunawardana et al. 2009).

The degradable component of MSW in most developing countries is comparatively higher than the developed countries (Hoornweg and Bhada-Tata 2012). It has been observed that about $90 \%$ of MSW in Sri Lanka are degradable organics in nature (Menikpura et al. 2007). The biological approaches, aerobic and anaerobic degradation, are considered as the most popular methods for the management of organic fraction of municipal solid wastes (OFMSW) at present (Tchobanoglous et al. 1993). Aerobic digestion or composting is a natural process by which degradable organic matter is transformed into complex stable compounds; carbon dioxide and water by aerobic microorganisms, and no readily degradable materials are found in the final stable product called compost (Gomez 2006; Iyengar and Bhave 2006). The separation of organic fraction from MSW is to be performed at the first instance for the composting. The separation of OFMSW after the collection of mixed waste is difficult and not feasible than the separation of waste at the places where waste is originated. More organic degradable waste generates from residencies, restaurants, guest houses, hotels and food stalls and on-site composting can be used for the management of degradable organic waste at such places (Hwang et al. 2002). Composting bins are more popular for waste management in residencies where a little amount of wastes are generated and the different composting bins have been developed and practiced in Sri Lanka (Premachandra 2006). The compost can easily be produced in a little effort using on-site composting bins in residencies (Papadopoulos et al. 2009; Kalamdhad and Kazmi 2007). However, those composting bins cannot be used for the production of compost in restaurants and guest houses since the amount of waste generated in such places are considerably higher than that of residencies. Therefore, it is a necessity to develop a suitable composting method for such places for the management of organic waste. In this study, we attempted to design, construct and evaluate a composting bin system for the management of organic waste through the production of compost in medium-scale waste generators $(25-50 \mathrm{~kg}$ of wastes per day) such as restaurants and guest houses.

\section{MATERIALS AND METHODS}

The location of the study was selected considering the availability of guesthouses and restaurants. At the beginning of the study, the waste generation rate of the restaurants and guesthouses were estimated. Based on the composition and waste generation rate, a sequential composter waste was designed. The designed composter was established and operated in the selected guesthouses. The important parameters for the evaluation of the process of composting were monitored and the quality parameters of compost were also determined at the end of the study for evaluating the quality of compost for agriculture.

\section{The geographical location of the study}

The location of the study is Kataragama which is situated in Monaragala District in Uva Province of Sri Lanka and its geographical coordinates are $6^{\circ} 25^{\prime} 0^{\prime \prime}$ North, $81^{\circ} 20^{\prime} 0^{\prime \prime}$ East. It is a religious town where Ruhunu Maha Kataragama devalaya, a shrine dedicated to Skanda-Murukan, a famous shrine and an ancient Buddhist temple are located. Therefore, different religious groups visit the area during the annual festival season as well as the holidays and weekends.

The population of the Kataragama divisional secretariat for the year 2007 was 20,945 indi- 
viduals. Its floating population increases tremendously greater than 20 times its inhabitants during festival season. It also becomes crowded at that time with many businessmen, transitory merchants, security persons, beggars and other service providers. And also there are many guesthouses and restaurants in Kataragama. As such, waste disposal is one of the major problems in the town.

\section{Site selection for the composter}

Easy access, availability of water and sufficient space for loading and unloading of waste were considered for the selection of suitable places for the construction of Sequential Batch Composters (SBC). Ceybank Resort (CR) and Elder's Residency (where elders are living by the government donations) at Kataragama town were selected for the construction of the SBCs.

Ceybank resort has 26 rooms and six halls which can be utilized to provide lodging facilities for approximately 175 persons per day. In addition to guests, 12 more persons work at Ceybank resort and approximately $150 \mathrm{~kg}$ of kitchen waste and $50 \mathrm{~kg}$ of garden waste was generated per week. The land area of the resort is about 0.2 ha.

Elder's Residency (ER) has the capacity of 45 regular residents and 7 employers and the

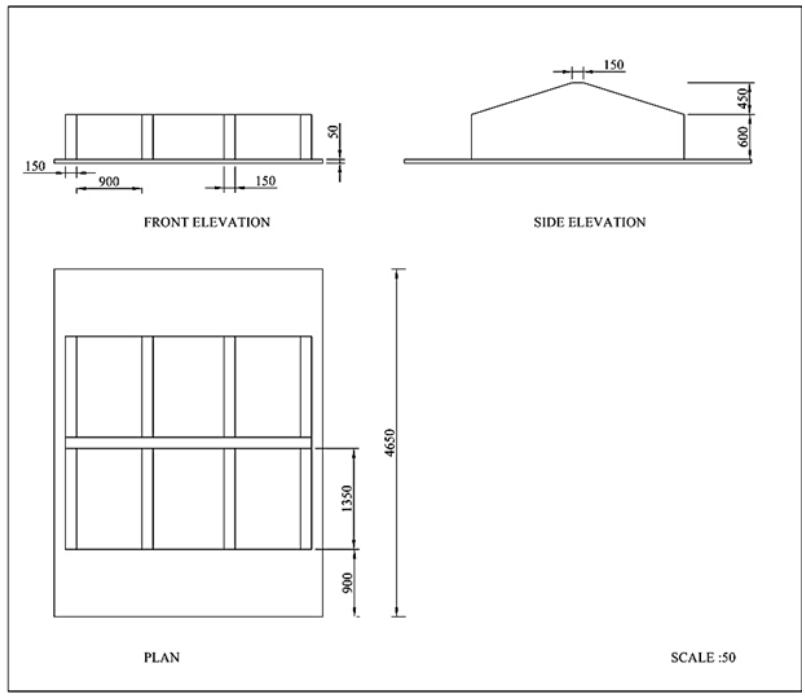

Figure 1: Plan of the SBC land area is about $0.6 \mathrm{ha}$, where approximately $200 \mathrm{~kg}$ of kitchen waste and $60 \mathrm{~kg}$ of garden waste per week are generated. SBCs were established at the very corner of the land in both locations to avoid unpleasant odors if any.

\section{Design and construction of sequential batch composters}

Sequential batch composters having six compartments were designed to install in the above two locations. The approximate volume of the single compartment of the SBC is about $0.65 \mathrm{~m}^{3}$. The plan of the SBC and the construction being carried out are shown in figures 1 and 2, respectively.

The sequential batch composters were constructed using bricks, cement and sand while the roof was made out of metal sheets. The dimension of a compartment was $1.35 \times 0.9 \times 0.45 \mathrm{~m}$ (lower side); $60 \mathrm{~m}$ (upper side). A concrete basement was also used to avoid any leaking out of leachate from the SBC into the nearby soil. Two and a halfcentimeter holes (diameter) were made on the walls of each compartment to facilitate the aeration and to avoid possible anaerobic digestion of waste. A wooden sliding door and metal roof (folding) for each compartment were made to easy loading and unloading of waste.

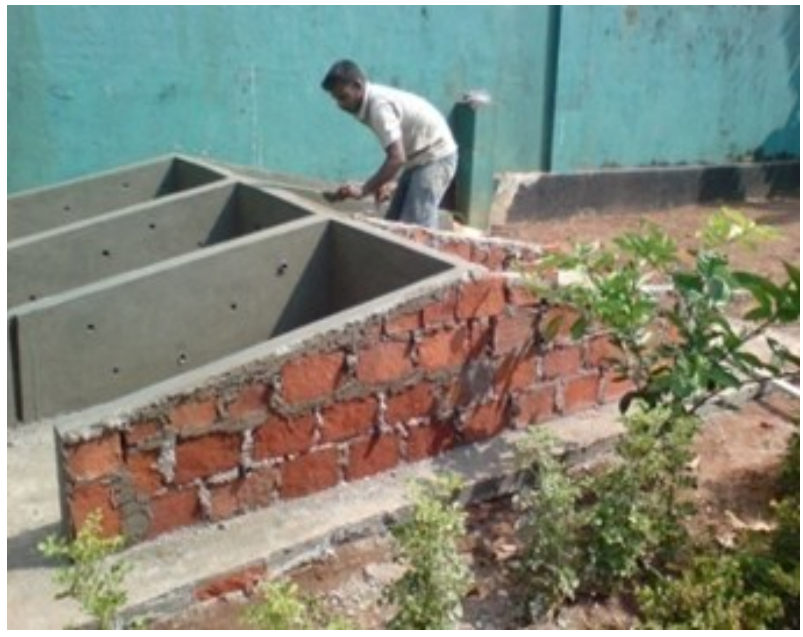

Figure 2: SBCs are being constructed 


\section{Physical and chemical analysis}

The physical and chemical parameters of raw material (compostable organic waste) before the composting, during composting and end the end of the composting process were determined for the monitoring of the composting process in SBCs and to determine the final quality of compost. The temperature was recorded using a digital thermometer (Tenma test equipment, 72/7712) while the air temperature was recorded using the standard thermometer. Grab samples were taken from each compartment of SBC and mixed, dried and powdered for the determination of total organic carbon, total Kjeldahl nitrogen, total phosphorus, electrical conductivity (EC), $\mathrm{pH}$, and heavy metals. Organic carbon was determined by Walkey and Black method while TKN was determined by the micro Kjeldahl method. Phosphorus was determined by acid digestion outlined in standard methods (Clesceri et al. 1999). Twenty grams of dried, powdered samples were taken and diluted with $40 \mathrm{~mL}$ of distilled water and shaken, kept for about one hour and measured the $\mathrm{pH}$ and $\mathrm{EC}$ (Gupta 2009). Heavy metals (Cd, Cr, $\mathrm{Cu}, \mathrm{Zn}$ and $\mathrm{Pb}$ ) were determined by an Atomic Absorption Spectrometer (5100 PC Spectrometer; PerkinElmer).

\section{Experimental Procedure}

The designed and constructed SBC was evaluated by following the two types of feeding techniques at ER and CR. The waste generation in CR was quite low during the study period. Therefore, we followed the four bin rotation (FBR) system while the six bin rotation (SBR) system was followed for ER.

In the four bin rotation system, first, waste was fed to the first bin of the composter for one week, and they were kept in the second bin during the second week. The waste coming from the second bin at the end of the second week was kept in the third bin for 1 to 3 weeks. Then, at the end of the fifth week, the wastes in the third bin (3, 4 and 5 weeks old) were transferred to the fourth bin and kept there for 6-7 weeks until the compost was matured. During the transferring of compost from one bin to another, waste was properly mixed and therefore, no additional mixing was required. However, the moisture of waste in bins was checked and water was added if required during transferring and mixing. The mixing of degrading wastes in the third and fourth bins was practiced once a week since the waste is kept for more than one week in those bins.

The waste was kept only one week in each of the first three bins of SBC during the six bin rotation system. During the fourth and fifth weeks, partially degraded wastes were kept in the fourth bin and then they were transferred to the fifth and sixth bin after keeping them only one week in each bin. In the sixth bin partially composted waste was kept for about 6-7 weeks to complete the composting process. In this rotation procedure, all six bins of the SBC were used while in the FBR system, only the first four bins are used for the composting process. The four bin rotation system is suitable for places where waste generation quite a law $(<25 \mathrm{~kg} /$ day). If the amount of waste is low in bins, it is difficult to maintain the proper moisture content suitable for composting. During the composting process, the volume of degrading waste is reduced due to microbial degradation, and therefore, to maintain proper moisture condition waste in two bins is needed to be mixed. Kitchen and garden waste are mixed (3:1) to maintain the suitable $\mathrm{C} / \mathrm{N}$ ratio before feeding to the composters. Moreover, garden waste plays the role of the bulking agent.

\section{RESULTS AND DISCUSSION Composition of waste}

The waste composition of two places where the SBCs are to be installed was determined. Kitchen waste generation was higher (75\%) than the garden waste $(25 \%)$ at Ceybank rest. Kitchen waste was comprised of rice $(56 \%)$, fruits $(20 \%)$ and vegetables $(24 \%)$ while dried 
leaves $(68 \%)$ and fresh leaves $(32 \%)$ were the main waste components.

The composition of waste in ER was almost similar to that of CR. Kitchen waste generation was $77 \%$ of total waste generation and the rest was garden waste (23\%). Rice, fruits and vegetables accounted for $60 \%, 14 \%$ and $26 \%$, respectively. Sixty-five percent of dried leaves and $35 \%$ of fresh leaves were found in garden waste. It appears that waste in two places is very good for composting with respect to biodegradability.

\section{Quality parameters of collected waste}

Selected physical and chemical parameters that are important for the microbial degradation of waste were determined in the two selected (ER and CR) places where SBCs are to be installed. Samples were collected separately as garden and kitchen waste and were analyzed for organic carbon, nitrogen, moisture content and organic matter (Table 1).

Carbon to nitrogen ratio which is very important for composting was also calculated. The general optimum $\mathrm{C} / \mathrm{N}$ ratio of raw material for composting is $25: 1$, a higher ratio reduces the degradation rate and lower material increases the nitrogen loss (de Bertoldi et al. 1983). Mixing of two types of raw materials gives approximately proper $\mathrm{C} / \mathrm{N}$ ratio for composting and it will help to maintain the proper moisture content also.

\section{Variation of temperature during the com- posting process in SBCs}

Temperature variation during the composting process shows the microbial activity, by which the ultimate quality of compost will be decided. Temperature variation of the compost indicates the existing degradation phases of the composting process. Three major temperature ranges of the composting process have been identified by Gomez (1998) as mesophilic $\left(10-40^{\circ} \mathrm{C}\right)$, thermophilic $\left(40-60^{\circ} \mathrm{C}\right)$ and cooling $\left(40-10^{\circ} \mathrm{C}\right)$ phases.

The temperature in two composting systems is almost similarly varied during the composting process and there is no significant difference $(p=0.98)$ in temperature variation among the two types of rotation (Fig 3). The maximum temperature in ER where the SBR followed and in $\mathrm{CR}$ where the four bin rotation was practiced were $61.7^{\circ} \mathrm{C}$ and $61.4^{\circ} \mathrm{C}$, respectively. However, the minimum temperature was similar $\left(27.6^{\circ} \mathrm{C}\right)$ in two locations. The temperature profile of this study has not followed the typical pattern (Adrian and Alex 2002). It appears that the initial mesophilic phase was only a few days in two composting bins. A similar pattern of temperature variation has been observed when kitchen waste is used as feeding material (Arslan et al. 2009). Kitchen waste contains a lot of food materials that are easily degradable. Therefore, the rate of microbial activity is prominent from the inception of the composting. Then, the temperature reached quickly to the thermophilic phase and continued up to 55 days. The waste used for the composting has the garden waste, which contains organic matter having cellulose that is quite resistant to microbial degradation. Therefore, the longer thermophilic phase is a good indicator for converting cellulose (resistant material) to compost by microbes involved in composting process (Bustamante

Table 1: Quality parameters of collected waste

\begin{tabular}{lllll}
\hline Parameter & \multicolumn{2}{l}{ Ceybank Rest } & \multicolumn{2}{l}{ Elder's Residency } \\
\hline & Garden waste & Kitchen waste & Garden waste & Kitchen waste \\
\cline { 2 - 5 } Moisture $(\%)(w b)$ & 52.70 & 78.51 & 23.90 & 69.64 \\
Organic carbon \% (db) & 54.43 & 51.36 & 55.74 & 51.79 \\
Nitrogen \% (db) & 1.91 & 2.41 & 1.6 & 1.96 \\
Organic matter \% (db) & 93.83 & 88.55 & 96.08 & 89.29 \\
C:N ratio & $28: 1$ & $21: 1$ & $35: 1$ & $26: 1$ \\
\hline
\end{tabular}



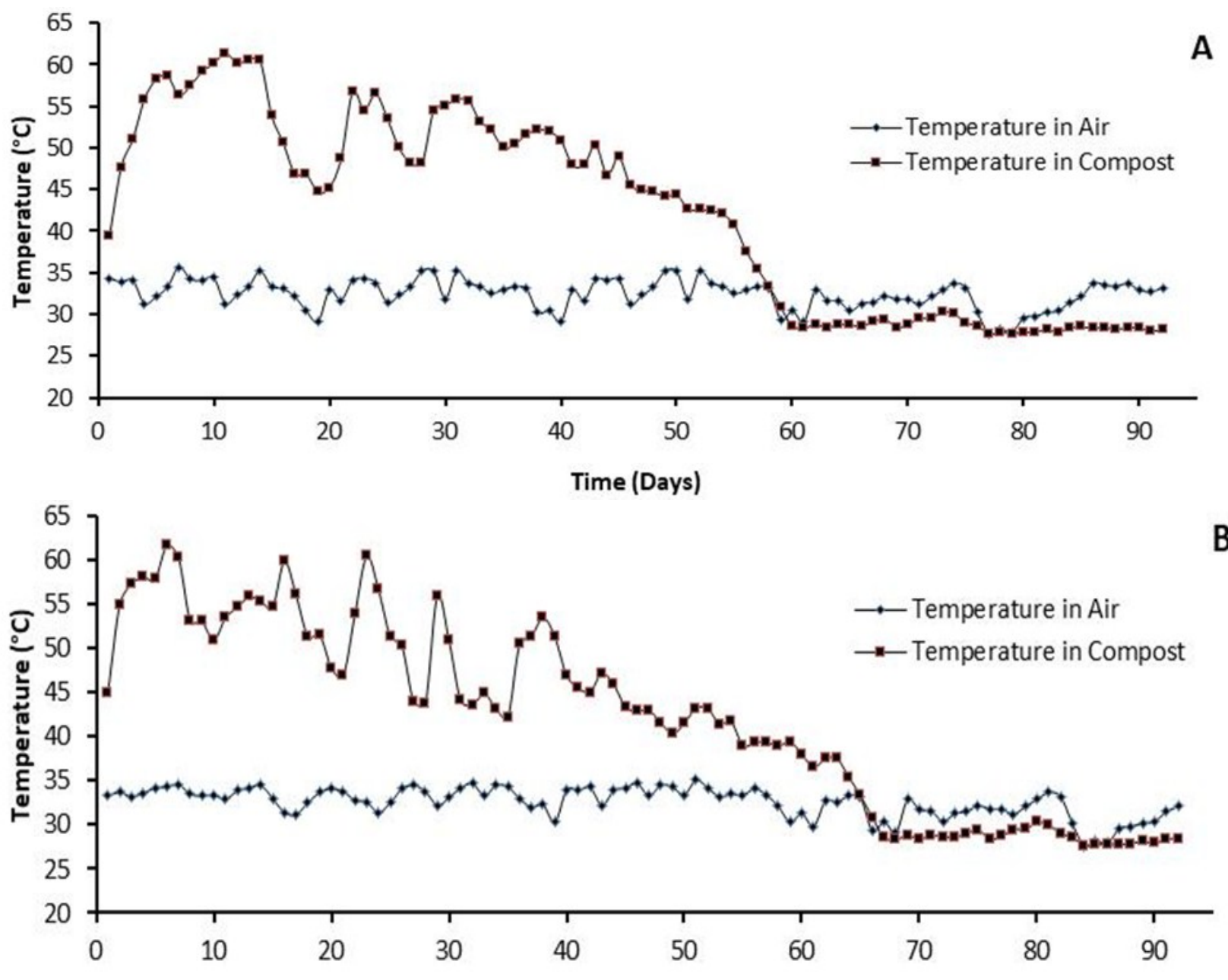

Time (Days)

Figure 3: Temperature variation during the composting process in SBCs at four bin rotation

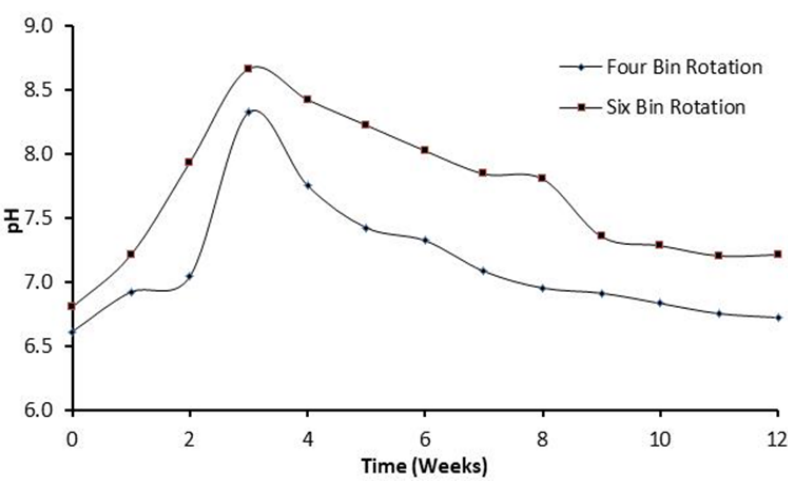

Figure 4: $\mathrm{pH}$ changes during composting in two SBCs

et al. 2008; de Bertoldi et al. 1983). The cooling phase of the composting process occurred until the end of composting process from 55 days onwards. Quite a constant temperature was noted during this period showing the compost being matured. The sudden temperature drops were observed when transferring the degradation waste from one bin to another in both SBCs (Fig. 3). Moreover, during transferring of waste, water was also sprayed when required and it also caused the reduction of temperature.

\section{pH of waste during composting}

The $\mathrm{pH}$ of the degrading waste varied between 6.8 and 8.7 in the SBR composter while it was between 6.6 and 8.3 in the FBR system (Fig. 4). The optimum values of $\mathrm{pH}$ should be 5.5 to 8 (de Bertoldi et al. 1983). In this study, a little high $\mathrm{pH}$ values than the optimum values were observed and it is basically due to 


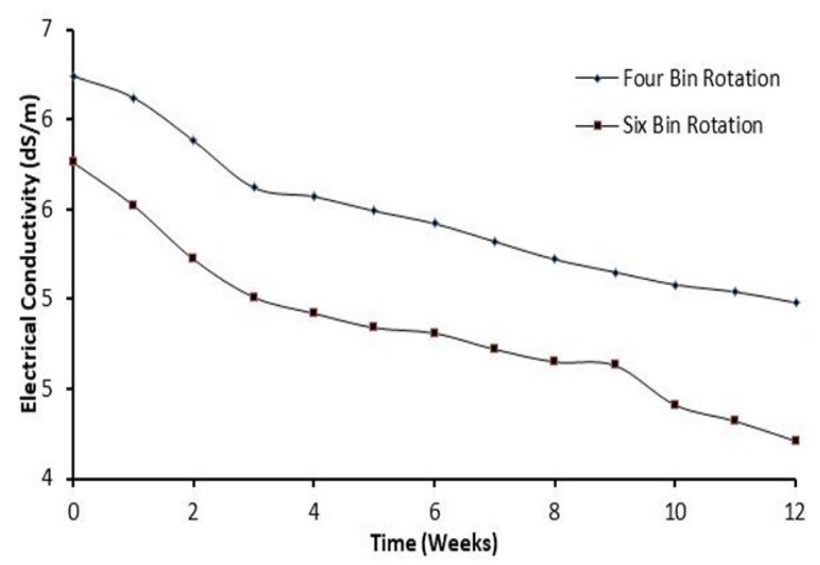

Figure 5: Variation of electrical conductivity during composting in SBCs

the presence of food materials containing more proteins.

Generally, $\mathrm{pH}$ at the beginning of composting is reduced due to the activity of acid-forming bacteria who break down complex organic materials to organic acids and their intermediates (de Bertoldi et al. 1983). However, in this study, from the inception of composting, $\mathrm{pH}$ tends to increase. This is basically due to the high temperature (fig. 3) which causes the volatilization of ammonia through nitrogen loss. High $\mathrm{pH}$ values were recorded during the fourth week of the feeding in both rotation systems and it is due to the emission of ammonia compounds in composting materials due to the decomposition of proteins in wastes (Pagans et al. 2006). High pH values observed in the SBR system were significant over the FBR system $(p=0.011)$. High $\mathrm{pH}$ in SBR may be due to the nutrient content of waste material. However, $\mathrm{pH}$ gradually decreases with time indicating the reduction of ammonia release towards the end of the composting process.

\section{Electrical conductivity in waste during composting}

EC reflects the salt content of the composting products and their suitability for plant growth. Soil amendments having high EC is not suitable for plants since plants experience water absorption difficulties because of the osmosis

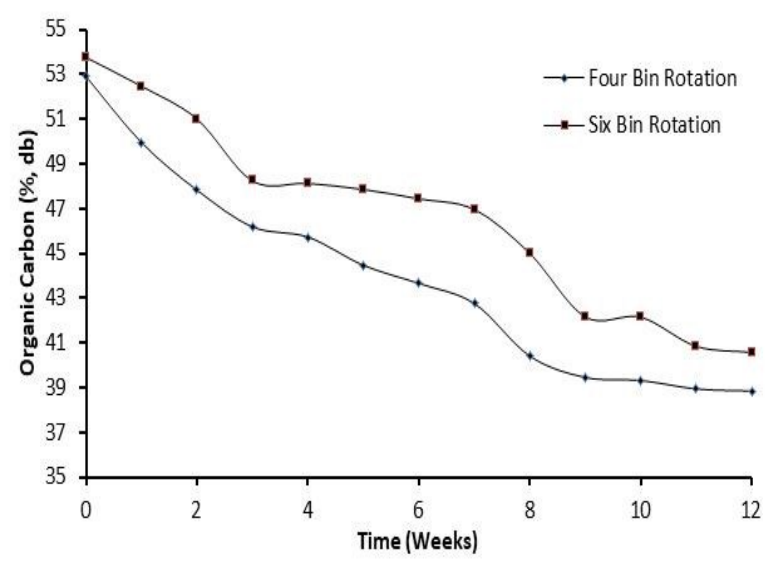

Figure 6: Changes of organic carbon during the composting of waste in two types of rotations in SBCs

affect and they are phytotoxic (Lasaridi et al. 2006).

Electrical conductivity was gradually reduced in both rotation systems during composting process (Fig 5). The electrical conductivity of the samples varied between 5.22 and $6.24 \mathrm{dS} /$ $\mathrm{m}$ in FBR, and 4.65 and $5.76 \mathrm{dS} / \mathrm{m}$ in SBR. Electrical conductivity is low in decomposing waste in the SBR system compared to the FBR system $(p=0.001)$. It indicates the soluble material is low in the SBR system. It appears that more soluble salts may have been removed from the compost in the SBR system.

\section{Carbon and Nitrogen ratio in decomposing waste}

Organic carbon in waste is gradually reduced from $\sim 54 \%$ to $\sim 39 \%$ in both rotation systems during the composting process due to the degradation of waste by aerobic microorganisms. The reduction of carbon during composting is attributed to the mineralization of organic matter resulting in the release of organic carbon as carbon dioxide (Said-Pullicino et al. 2007). The energy required for microbial growth and development was taken by the oxidation of organic matter and heat was also generated resulting in the increasing temperature. Therefore, organic carbon content should be gradually reduced. The reduction of organic carbon was observed as expected 
(Fig. 6). Even though two rotation systems show different percentages of organic carbon, the changes are not significant $(p=0.12)$.

\section{Nitrogen in decomposing waste}

The nitrogen content of waste is one of the most important nutrients for the success of the composting process. Organic nitrogen existed as part of the structure of proteins is mineralized to ammonia and nitrate by ammonification and nitrification reactions (Silva et al. 2007). At the early growth stages of the microorganisms, carbon utilization is high. Therefore, the carbon content was rapidly de- creased at the early stages of the composting process. Loss of nitrogen from waste as ammonia is considerably less when compared with carbon and it causes a rapid decrease of the dry weight of the waste, increasing the nitrogen content. Therefore, the nitrogen content of the degrading waste should generally be increased as observed (Arslan et al. 2009). However, in this study, the nitrogen content of degradation waste is initially increased and then decreased (Fig. 7). Nitrogen reduction may be due to the removal of nitrogen from degrading wastes as leachate.

Table 2: Selected physical and chemical properties of compost

\begin{tabular}{llll}
\hline Properties & Standard Value & Four Bin Rotation & Six Bin Rotation \\
\hline Color & $\begin{array}{l}\text { Brown / grey to dark } \\
\text { black }\end{array}$ & $\begin{array}{l}\text { Brown / grey to } \\
\text { dark black }\end{array}$ & $\begin{array}{l}\text { Brown / grey to } \\
\text { dark black }\end{array}$ \\
Moisture content $\left(\%\right.$ in $\left.\mathrm{db}^{*}\right)$ & $<25$ & 24.68 & 20.27 \\
$\mathrm{pH}$ & $6-8$ & 7.34 & 7.21 \\
EC $(\mathrm{dS} / \mathrm{m})$ & $0.5-4$ & 4.98 & 4.21 \\
Nitrogen $(\%$ in db) & $>1.0$ & 2.04 & 1.89 \\
C:N ratio & $10-25$ & $19: 1$ & $22: 1$ \\
Phosphorous $(\%$ in db) & $>0.5$ & 0.38 & 0.62 \\
Organic Carbon $(\%$ in db) & $>20$ & 38.85 & 40.58 \\
Cadmium $\left(\mathrm{mgkg}^{-1}\right)$ & $<10$ & Not detected & Not detected \\
Chromium $\left(\mathrm{mgkg}^{-1}\right)$ & $<1000$ & 12.47 & Not detected \\
Copper $\left(\mathrm{mgkg}^{-1}\right)$ & $<400$ & 4.96 & 2.4 \\
Zinc $\left(\mathrm{mgkg}^{-1}\right)$ & $<1000$ & 48.24 & 95.99 \\
Lead $\left(\mathrm{mgkg}^{-1}\right)$ & $<250$ & Not detected & Not detected \\
\hline
\end{tabular}

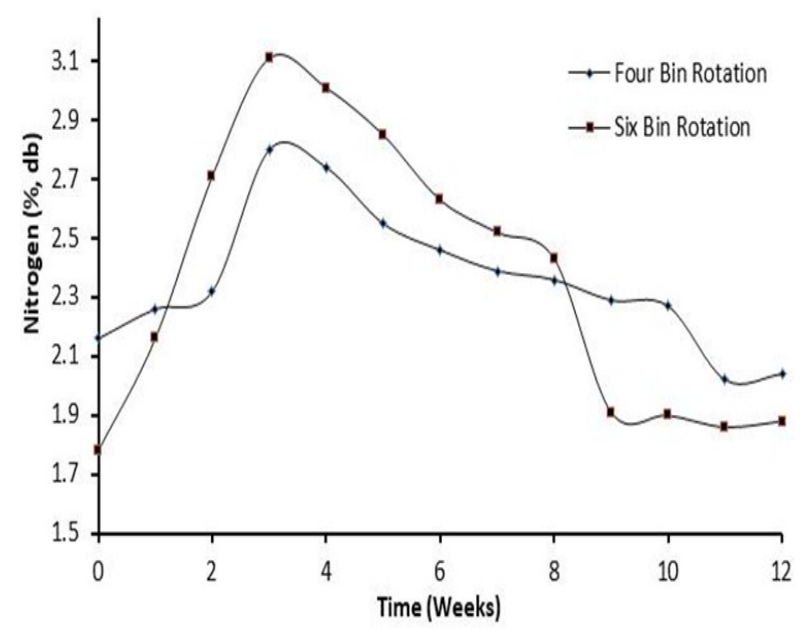

Figure 7: Changes of organic carbon during the composting of waste in two types of

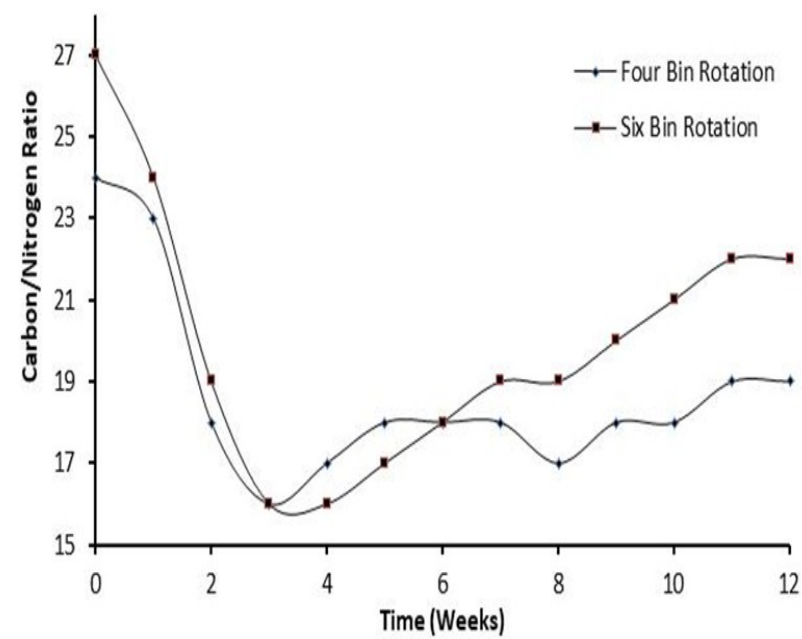

Figure 8: Changes of Carbon to Nitrogen ratio during the composting of waste in two 


\section{Variation of $C: \mathrm{N}$ ratio}

At the first stages of the composting process, the $\mathrm{C}$ : $\mathrm{N}$ ratio is gradually decreased because of the reduction of the carbon content over nitrogen. In later stages, $\mathrm{C}$ : $\mathrm{N}$ ratio is increased basically due to the reduction of nitrogen (Fig. 7). Finally C: N ratio of compost reached around 19-22 in two types of rotation systems (fig. 8) complying with recommended values of matured compost (Sri Lanka Standard 2003). The reduction of the $\mathrm{C} / \mathrm{N}$ ratio during composting is an indicator for stabilizing the compost. However, the final C/ $\mathrm{N}$ ratios depend upon the characteristics of the feeding material (Silva et al., 2007). Usually, compost is considered stable when the $\mathrm{C} /$ $\mathrm{N}$ ratio is approximately 17 or less unless lignocellulosic material remains (Silva et al. 2007). It seems that the $\mathrm{C} / \mathrm{N}$ ratio of this study is greater than 17 indicating the instability of compost. However, Forster et al. (1993) reported that the $\mathrm{C} / \mathrm{N}$ ratio is not a good indicator for the determination of maturity of compost. The compost production systems having $\mathrm{pH}$ over 7 , the $\mathrm{C} / \mathrm{N}$ ratio may change very little during composting because of the carbon and nitrogen loss simultaneously as carbon dioxide and ammonia (Sullivan and Miller 2001).

\section{Quality of compost}

The determined values of quality parameters were compared with the standard values outlined by Sri Lanka standard institute (Sri Lanka Standard 2003). Color, moisture content, $\mathrm{pH}$, nitrogen, $\mathrm{C} / \mathrm{N}$ ratio, and organic carbon content of the final compost were in the range of standard compost while EC and particle sizes are different from the standard values. Available phosphorous from the compost in SBR was within the recommended level while it was not in the recommended range in compost taken from the FBR composter. Table 2 shows the quality parameters of compost produced in SBCs and the standard values of compost produced from domestic waste.

\section{CONCLUSION}

The quality parameters, which are used for evaluating the compost quality, in both rotation systems (FBR and SBR) are almost similar to the compost standards given by Sri Lanka standard institute. The four bin rotation system is quite complex than the SBR system and therefore, the SBR system can easily be recommended for the production of compost. However, if the availability of waste is low, the FBR system can also successfully applied. Based on the results of the study, the designed SBC can be successfully used for the production of compost from kitchen and garden waste generated from medium-scale restaurants.

\section{ACKNOWLEDGEMENT}

Mr. K Weeratunga Arachchi, Chief Executive, Alliance for Appropriate Technology Exchange is greatly appreciated for providing financial support and logistics to carry out the research study successfully.

\section{REFERENCES}

Adrian J Whittle and Alex J Dyson 2002 The fate of heavy metals in green waste composting. The Environmentalist. 22: 13-21.

Arslan E, İpek U, Öbek E, Topal $M$ and Baykara O 2009 In-vessel composting: I. Kitchen wastes. Uludağ Üniversitesi Mühendislik-Mimarlık Fakültesi Dergisi. 14(2): 33-46.

Bustamante MA, Paredes C, Marhuenda-Egea FC, Pérez-Espinosa A, Bernal MP and Moral R 2008 Co-composting of distillery wastes with animal manures: Carbon and nitrogen transformations in the evaluation of compost stability. Chemosphere. 72:551-557.

Hoornweg D and Bhada-Tata P 2012 What a waste: A global review of solid waste management. Urban Development \& Local Government Unit World Bank 1818 H Street, NW Washington, DC 20433 USA. 
Clesceri LS, Greenberg AE and Eaton AD (Eds.) 1999 Standard Methods for the Examination of Water and Wastewater (20th ed.). American Public Health Association, American Water Works Association, Water Environment Federation.

de Bertoldi M, Vallini G and Pera A 1983 The Biology of Composting: A Review. Waste Management \& Research. 1 (1):157-176.

Forster JC, Zech W and Würdinger E 1993 Comparison of chemical and microbiological methods for the characterization of the maturity of composts from contrasting sources. Biology and Fertility of Soils. 16(2): 93-99.

Gomez A 1998 The evaluation of compost quality. TrAC Trends in Analytical Chemistry. 17(5): 310-314.

Gomez RB 2006 The use of respiration indices in the composting process: a review. Waste Management \& Research. 24(1): 37-47.

Gunaruwan TL and Gunasekara WN 2016 Management of Municipal Solid Waste in Sri Lanka: A Comparative Appraisal of the Economics of Composting. NSMB Journal of Management. 2(1): 27-45.

Gunawardana EGWW, Basnayake BFA, Shimada S and Iwata, T 2009 Influence of biological pre-treatment of municipal solid waste on landfill behaviour in Sri Lanka. Waste Management \& Research. 27(5): 456-462.

Gupta PK 2009 Soil, plant, water and fertilizer analysis. Agrobios, India.

Hwang EJ, Shin HS and Tay JH 2002 Continuous feed, on-site composting of kitchen garbage. Waste Management \& Research. 20(2): 119-126.

Iyengar SR and Bhave PP 2006 In-vessel composting of household wastes. Waste Management. 26(10): 10701080.

JICA. 2016 Data Collection Survey on Solid Waste Management in Democratic
Socialist Republic of Sri Lanka. Retrieved from http:// open_jicareport.jica.go.jp/ pdf/12250213.pdf

Kalamdhad AS and Kazmi AA 2007 Rotary Drum Composting of Mixed Organic Waste based on Different C/N Ratios. In Proceedings of the International Conference on Sustainable Solid Waste Management (pp. 258-265). Chennai, India.

Lasaridi K, Protopapa I, Kotsou M, Pilidis G, Manios T and Kyriacou A 2006 Quality assessment of composts in the Greek market: The need for standards and quality assurance. Ournal of Environmental Management. 80: 58-56.

Menikpura SNM, Ariyawansha SWGRTK, Basnayake BFA and Tharinda YGWGMC 2007 Design and Development of Biofilters for Controlling Odor Emissions from Composting of Municipal Solid Waste. In Proceedings of the International Conference on Sustainable Solid Waste Management (pp. 250-257). Chennai, India.

Pagans E, Barrena R, Font X and Sánchez A 2006 Ammonia emissions from the composting of different organic wastes. Dependency on process temperature. Chemosphere. 62:15341542.

Papadopoulos AE, Stylianou MA, Michalopoulos CP, Moustakas KG, Hapeshis KM, Vogiatzidaki EEI and Loizidou MD 2009 Performance of a new household composter during in-home testing. Waste Management. 29(1): 204-213.

Premachandra HS 2006 Household Waste Composting \& MSW Recycling in Sri Lanka. In Asia 3R conference. Tokyo. Retrieved from https://www.env.go.jp/ recycle/3r/en/asia/02_03-3/08.pdf

Said-Pullicino D, Erriquens FG and Gigliotti G 2007 Changes in the chemical characteristics of water-extractable organic matter during composting and their 
influence on compost stability and maturity. Bioresource Technology. 98 (9):1822-1831.

Silva MTB, Menduíña AM, Seijo YC and Viqueira FD 2007 Assessment of municipal solid waste compost quality using standardized methods before preparation of plant growth media. Waste Management \& Research. 25 (2): 99-108.

Sri Lanka Standard 1246. (2003). Specification for compost from municipal solid waste and agricultural waste. Sri Lanka Standard Institution, Colombo, Sri Lanka.

Sullivan D and Miller R 2001 Compost Quality Attributes, Measurements, and Var- iability. In Compost Utilization In Horticultural Cropping Systems. In P. J. Stoffella \& B. A. Kahn (Eds.), Compost utilization in horticultural cropping systems. Lewis Publishers is an imprint of CRC Press LLC.

Tchobanoglous $\mathrm{G}$, Theisen $\mathrm{H}$ and Vigil $\mathrm{S}$ 1993 Integrated solid waste management, engineering principles and management issues. New York, USA: McGraw-Hill Book Company.

Vuai SAH 2010 Characterization of MSW and related waste-derived compost in Zanzibar municipality. Waste Manag Res. 28(2): 177-184. 